REGARDS

SUR LECONOMIE ALLEMANDE

BULLETIN ECONOMIQUE DU CIRAC
Regards sur l'économie allemande

Bulletin économique du CIRAC

$78 \mid 2006$

Varia

\title{
Entreprises familiales
}

BÖLLHOFF Christian et al., Spitzenleistungen in Familienunternehmen. Ein Managementhandbuch / SCHERER Stephan et al., Familienunternehmen. Erfolgsstrategien zur Unternehmenssicherung

\section{OpenEdition}

Édition électronique

URL : http://journals.openedition.org/rea/474

DOI : $10.4000 /$ rea. 474

ISBN : 978-2-8218-0852-2

ISSN : 1965-0787

Éditeur

CIRAC

Édition imprimée

Date de publication : 1 octobre 2006

ISSN : 1156-8992

Référence électronique

"Entreprises familiales », Regards sur l'économie allemande [En ligne], 78 | octobre 2006, document 7 , mis en ligne le 24 avril 2008, consulté le 22 septembre 2020. URL : http://journals.openedition.org/rea/ 474 ; DOl : https://doi.org/10.4000/rea.474

Ce document a été généré automatiquement le 22 septembre 2020.

(c) CIRAC 


\section{Entreprises familiales}

BÖLLHOFF Christian et al., Spitzenleistungen in Familienunternehmen. Ein Managementhandbuch / SCHERER Stephan et al., Familienunternehmen. Erfolgsstrategien zur Unternehmenssicherung

\section{RÉFÉRENCE}

BÖLLHOFF Christian et al., Spitzenleistungen in Familienunternehmen. Ein Managementhandbuch, Coll. Handelsblatt-Bücher, Schäffer Poeschel Verlag, Stuttgart, 2006, $261 \mathrm{p}$.

SCHERER Stephan et al., Familienunternehmen. Erfolgsstrategien zur

Unternehmenssicherung, Verlag Recht und Wirtschaft, Francfort/Main, 2005, 483 p.

1 "Il ne suffit pas de nous lamenter sur la politique économique... nous devons bien plutôt nous souvenir de notre mission intrinsèque : découvrir et mettre à profit les opportunités que nous fournit le marché ». Cette phrase d'introduction, signée de Ludwig Georg Braun, président de la fédération des CCI, résume parfaitement le propos de ce précis de conseil juridique (SCHERER et al.) à destination des entreprises familiales (95\% des sociétés en Allemagne). Il met un accent particulier sur les modalités de succession, vive préoccupation des entreprises dont la majeure partie est confrontée aujourd'hui à ce problème. L'ouvrage de BÖLLHOFF et al., pour sa part, est plus axé sur le management et la performance globale. Il fourmille d'exemples concrets, autant de portraits des grands noms de l'économie allemande : de Rodenstock à Falke en passant par Merz, Otto ou Wempe. On en retiendra l'importance accordée aux valeurs dans le statut de société le plus répandu outre-Rhin : $95 \%$ des entreprises sont familiales... (ib) 